\title{
Why is China the World's Leader of Solar Water Heater Production and Consumption?
}

\author{
${ }^{1}$ Lee Liu and ${ }^{2}$ Jie Liu \\ ${ }^{1}$ School of Environmental, Physical and Applied Sciences, \\ University of Central Missouri, Humpreys 225, Warrensburg, MO 64093, USA \\ ${ }^{2}$ Jilin Province Environmental Monitoring Center, Changchun, Jilin, China
}

Received 2012-05-11, Revised 2012-11-08; Accepted 2013-05-15

\begin{abstract}
Sustainable energy programs in developing countries face many challenges. The purpose of this research is to examine why China has been successful as the world's leader of Solar Water Heater (SWH) production and consumption. The study is based on field work in China in the past two years in areas where SWHs are widely used. The results may help provide a better understanding of the main drivers for the rapid growth of renewable and sustainable energy and develop associated policies. The research is based on data from current reports on SWH production and consumption in China and field investigations in Chinese cities and rural areas where SWHs are widely used. The findings are limited by the availability of data and the varied physical and cultural conditions in China. The research finds that several factors may have contributed to China's leadership in this area: governmental policies, innovations in technology, low costs of labor, low interest rates, government incentives, a large market, a new installation, shortage of electricity and social acceptance. China's SWH production and consumption is mainly due to economic incentives and cultural appeal instead of consumer environmental concerns. The Chinese SWH experience confirms earlier findings that low levels of development should not prevent countries from having effective environmental institutions and policies. In addition to technological innovations, policies for renewable and sustainable energy need to pay more attention to economic, political and cultural factors.
\end{abstract}

Keywords: Solar Water Heaters, Energy Policy, Renewable Energy, Sustainable Development, Sustainable Energy, Developing Countries, Economic Incentives, Cultural Factors

\section{INTRODUCTION}

China is currently the largest developing country with a rapidly growing economy and high energy demands. The annual accumulative total capacity of electric energy is about 0.1 billion $\mathrm{kW}$, about $90 \%$ of which is generated with fossil fuel resources (Liu et al., 2010) and nearly 75\% from coal (Wang, 2010). Amid accelerating environmental degradation and grave challenges to sustainability (Economy, 2004; Liu, 2008; 2009; 2010a; 2011; Watts, 2010a; 2010b), China has been promoting "green growth," as some other AsianPacific countries have (CD, 2010). According to GAD
(2013), China now leads the world in total renewable power capacity. New investments in core clean energy leapt 53\% in China, 2009. More than any other country in the world, China added $37 \mathrm{GW}$ (gigawatts) of renewable power capacity, for a total of $226 \mathrm{GW}$, or $11 \%$ of the world total. China surpassed the US in 2009 as the country with the greatest investment in clean energy. Also in 2009, China produced $40 \%$ of the world's solar PV supply, 25\% of the world's wind turbines (up from $10 \%$ in 2007) and $77 \%$ of the world's solar hot water collectors. Solar Water Heaters (SWHs) are the most popular means of solar energy utilization because of the technological feasibility and economic Humpreys 225, Warrensburg, MO 64093, USA Tel: 6605438789 Fax: 6605438142 
attraction, compared with other kinds of solar energy utilization (Wang and Hua, 2005). Furthermore, 30.5 million rural households use biogas digesters (TTN, 2009a; 2009b; 2009c; CCT, 2009).

Numerous renewable energy electrification programs have been implemented in developing countries over the past decade but have had limited success (Urmee and Harries, 2009). Why has China been able to make such impressive progress? China might provide interesting lessons for other developing countries. With that question in mind, we visited various parts of China in the last two years. We were amazed at how fast people have been installing SWHs on their rooftops, especially in Jiangsu and Zhejiang provinces. The Chinese consumers we talked to believe that the cost of using SWHs was lower than using electric or gas water heaters. The initial cost is higher but consumers do not need to pay as much operation costs even if an electric backup system is used with solar water heaters. Since 2006, Miyun County in the north of Beijing has been China's leader in energy saving and pollution reduction while improving both the environment and the economy (Xia 2007; Chen, 2010; CN, 2010). Miyun villages have increased solar energy and biogas uses (Xia, 2007; CN, 2010). Solar street lights have been widely used and new constructions follow the local new green-building codes. After shutting down all of its worst polluters, including paper-mills and coal and mineral mines, Ninghai County in Zhejiang Province focuses on "green growth" with mostly locally-developed innovations to produce low-cost solar energy products in 18 factories with a production capacity of over 100 megawatts (Ninghai, 2010). Partly due to the innovations, Ninghai's solar water heaters are highly profitable to produce and less expensive to use than electric water heaters. Solar water heaters are installed in about 37\% of the new houses in rural areas (Liu, 2010b). Also, Ninghai contributes 530 million watts of electricity annually to the regional power grid.

Conventional theories of environmentdevelopment relations tend to regard income as the dominant explanation for variations in environmental success (Esty et al., 2008; VanderZanden, 2008). The notion of the environmental Kuznets Curve (EKC) argues that the initial stages of economic growth are accompanied by increasing environmental degradation. Once per capita income exceeds a given threshold, not only does the structure of the economy change, but people can also afford to demand a better environment (Beckerman, 1992; Shafik, 1994). There has been an intense debate on the applicability of the
EKC. Numerous environmental and development economists cite a great deal of evidence to suggest that environmental degradation can be stopped and conditions can improve, as has happened in many areas of the world (WB, 1992; Scherr and Yadav, 1996; Johansson, 1998). Some have regarded the EKC as the optimal growth path (Chimeli and Braden, 2011). Consequently they support the "grow first and clean up later" approach to development. That approach has attracted a great deal of attention in development and environmental policy (Beckerman, 1992; WB, 1992; Ezzati et al., 2001).

Accordingly, more developed economies, such as the United States, Western European countries and Japan, are expected to be the leaders in renewable energy uses. To some extent, that is true as these countries have led the world in renewable energy research and development and are top countries using renewable energy technology. However, China appears to be ahead of the developed countries in SWH production and consumption. Conventional theories, such as the EKC model, do not seem to be adequate in explaining the Chinese experience.

\subsection{Recent Research Suggests that Low Levels of Development Should not Prevent Countries from Having Effective Environmental Institutions and Policies (Dasgupta et al., 2006)}

The EKC reflects only one of many nature-society relations and paths to sustainability. Developing areas should move beyond the EKC and take a sustainability approach at early stages of development (Liu, 2008; 2011). This article examines why China has been the world's leader of SWH production and consumption. Research indicates that the potential market of SWHs in Taiwan is associated with the climatic conditions, population structure, urbanization, building type of housing and status of new construction, in addition to cost of SWHs and energy price index (Chang et al., 2008). India also has a vast theoretical potential of $\mathrm{CO} 2$ mitigation by the use of SWHs, which may become viable through higher level of government subsidy (Purohit and Michaelowa, 2008). Deng et al. (2009) present a thorough review on recent advances in direct solar thermal power generation and conceive that efficiency and cost are the two most important factors in determining whether or not a solar power generation technology can be applied in large scale. This stduy may be useful in providing better understanding of main 
drivers for rapid growth of renewable energy and help further develop policies for sustainable development.

\section{METERIALS AND METHODS}

The research is based on data from current reports on SWH production and consumption in China, the Renewables Global Status Reports by the Renewable Energy Policy Network for the 21st Century and the Global Trends in Green Energy reports by the United Nations Environmental Program and field investigations. In the summers of 2009 and 2010 we visited Chinese cities and rural areas in Beijing and the provinces of Zhejiang, Shanghai, Jiangsu, Liaoning and Jilin. Those places were studied partly because SWHs are widely used there and we were doing field research for a different project there. We toured nine cities and counties in Beijing and the five provinces where we also interviewed some residents and government officials. There were no government records to provide detailed information so the results are mainly qualitative in nature. The findings are limited by the availability of quantitative data, the small number of places we visited and the variety of physical and cultural conditions in China. However, this study provides a basis for further investigations.

\section{RESULTS}

We find that several factors have contributed to China's leadership in SWH production and consumption.

Governmental policy to cope with environmental and development pressure. As one of the most polluted and rapidly industrializing countries in the world, China faces an accelerating demand for energy and especially green energy, to meet challenges of sustainability. According to Wang (2010), China's total installed electrical power capacity reached $700 \mathrm{GW}$ by the end of 2007 and is predicted to surpass $900 \mathrm{GW}$ in 2010. The rapid increase in energy demand and increasing global warming have pressured China to change its current electrical power structure where coal power accounts for nearly $75 \%$ of the total electric power generation. The government does not have many options and is forced to take a green growth approach. SWH production benefits from government incentives such as low interest rates and a government policy of steering loans to renewable energy. China's Photovoltaic (PV) industry has been expanding quickly partly due to government support (Zhao et al., 2011). This agrees with Urmee and
Harries (2009) who found that adequate funding support and the use of appropriate financing mechanisms were considered to be the most critical factors for program success in Asia and the Pacific regions.

Innovations in technology. According to Xiangnian (2010), China is believed to be one of the countries that started solar energy development early and has accumulated much experience and gained much technological advancement. Recent innovations in solar water heater technologies are regarded as a key element in making the product cheaper. Cheaper products enhance the consumption and thus production of SWHs.

High Profitability. A surprise finding is that SWH production has been a high profit industry in China (WN, 2009; CNEN, 2010). Solar energy has been praised for its positive environmental aspects as a clean renewable energy. However, its use has been limited by the high cost of production. In the United States, many attempts by the government to increase solar energy uses have achieved limited results, mainly due to the cost factor. China has been able to produce SWHs cheaply because of low costs of labor. Though wages have risen in recent years, Chinese workers are still paid only a fraction of what workers are paid in more developed countries. They often receive little medical or social benefits. SWH assembly and installation is labor intensive. Another important reason is that SWH production in China is often of substandard product quality, which contributes to lower production cost. Reports say that about $70 \%$ SWHs in China have been low quality. They break down quickly. Some SWHs are not operating properly due to defects. Internet discussions and Blogs indicate that some SWH consumers are disappointed. A small scale SWH production line can cost as little as US $\$ 15,000$ and a household can start the business easily, while the profit is reported to be as high as $50 \%$, compared to only $10 \%$ for electronic industries (WN, 2009). Due to low startup cost and high profit, investment pours into the business. The SWH industry has been booming in China. The number of registered SWH producers increased from about 1,000 in 2005 (Wallace and Wang, 2006) to over 5,000 in 2009 (CSEN, 2009). Among the over 5,000 SWH producers in 2009, only ten were major ones and about 1,000 are medium size, while the others are small scale, local or even household operated firms.

Competitive prices. SWHs are economically feasible to use due to low product prices at about US\$200 per unit. While electric water heaters cost about US\$50 and gas water heaters cost about US $\$ 100$ 
(Liu et al., 2010), their operating costs are much higher. It saves money to use SWHs in the long run.

A large market, especially for SWH uses in the countryside. China has the largest population in the world and a high potential for the SWH market. Recent SWH market expansion benefited from rural installations, which have been supported by government incentives, including matching funds to consumers. For example, the Yunnan Provincial Government pays 500 Yuan for each SWH installed in rural areas (YPAIO, 2009). SWHs have been mainly installed in urban areas where incomes are higher. By 2004, urban areas used to have $90 \%$ of China's SWHs installations, $30 \%$ in large cities and $60 \%$ in suburban areas and small cities (Luo and Shi, 2004). The recent government policy has been to promote SWH uses in the countryside as a part of rural development program, which is a huge potential market. Rural areas typically have individual homes which enable each household to have a SWH on its rooftop. It would be more costly for high rise apartment buildings in urban areas to install SWH for each apartment.

A new installation. Due to poverty, most rural homes and some urban homes used to have no water heaters until recently. SWHs in this case were not a replacement but usually a new installation. In the more developed countries, consumers frequently face a choice between installing a SWH or continuing to operate an electric or gas water heater that has already been installed. It is sometime economically feasible to install a new SWH, but not so to use it to replace an electric or gas heater which may still be working. More developed countries, such as the United States, have not experienced similar expansion of solar water heater consumption partly because homes already have water heaters. If an electric or gas water heater is still working it would not be cost effective to replace it with a solar water heater.

Lack of electricity and gas supplies. Shortage and unreliability of electricity supply in China makes the cost of electricity relatively high in comparison to income levels in the countryside. It also means that electricity supply is limited and unreliable. Daily power outages and quotas are not uncommon in many rural areas. To meet the emission target, some local governments have been turning off electricity supply. SWHs thus have become an alternative to ease the energy problems, as gas supply is often not available in many rural areas. Electric and gas heaters are also more likely to cause safety problems due to poor maintenance.
Cultural acceptance. A change of life style influenced by western cultures makes SWH popular similar to a cell phone or air conditioning in many areas we visited. A SWH unit on your rooftop means you have hot water in your home, you can take a bath often and you are clean and modern. Most people we talked to believed that homes actually looked better with a SWH unit on their rooftops. Yuan et al. (2011) found a considerable high level of social acceptance and public awareness of solar water heaters in Shandong Province. In the more developed countries such as the United States, people may prefer the traditional appearance of the rooftops. Many subdivisions may have home owner associations, which do not allow such a change in the physical appearance of the home. Rooftop installation will certainly change the traditional appearance of homes. It is, in many cases, not considered the better looking option. It will take time for the culture to change to accept the new appearance.

\section{DISCUSSION}

As a developing economy, China performs exceptionally well in its renewable and sustainable energy development. The Chinese SWH experience raises questions about conventional wisdom on environment-development relations. It confirms earlier findings that low levels of economic development should not prevent countries from having effective environmental institutions and policies. Developing areas are capable of taking a sustainability approach through innovative policies and management approaches.

The findings indicate that the main drivers for rapid growth of renewable and sustainable energy in China are both economic and political. China's SWH production and consumption is mainly due to economic incentives and cultural appeal instead of consumer environmental concerns. Government direct subsidy was also the driving force of SWH market expansion in Taiwan (Chang et al., 2008; 2011), however, the highlevel subsidy might have a negative impact on SWH system design and post-installation service (Chang et al., 2011). In China, cheap SWH products also result in low quality which is a challenge to further SWH promotion. Wallace and Wang (2006) pointed out that quality control and poor quality products were major issues, affecting customer confidence and acceptance of the product. Similar problems of poor quality products have 
been reported of Solar Home Systems (SHS) in Sri Lanka (Laufer and Martina, 2011).

Besides, PV production is associated with contamination with acidic and alkaline waste water and heavy metals. China's low production standards cause concerns about the negative environmental health impacts to SWH workers. Low quality products, partly for export, lead to an increase in solid waste and other environmental concerns. It is important to make green equipment cheap in price but not cheap in quality. Low quality products become throw away items after minimal use, increasing environmental pollution. It is necessary to regulate the industry to meet environmental health standards. Many issues need to be addressed through policy innovations to make the SWH production and consumption sustainable.

\section{CONCLUSION}

China needs to develop SWH production standards and the SWH industries need to provide better post sale services so that SWH consumption may be sustainable. China should promote diversified renewable energy consumption due to its varied climate conditions. Solar energy depends on sunshine that is not distributed evenly. Places with favorable radiation should certainly promote solar energy while places with a lack of radiation but with warmer climate may go with heat pump water heaters, though it may be better to use a heat pump powered by solar energy. More and more Chinese are talking about heat pump water heaters, which we think will become more popular in some areas. The research findings indicate that policies for renewable and sustainable energy need to pay more attention to economic, political and cultural factors, in addition to technological innovations.

\section{REFERENCES}

Beckerman, W., 1992. Economic Growth and the Environment: Whose growth? whose environment? World Dev., 20: 481-496. DOI: 10.1016/0305750X(92)90038-W

CCT, 2009. More rural areas turn to biogas. China Central Television.

CD, 2010. China moves fast toward green growth: CEO of danfoss. China Daily.

Chang, C.Y., J.C.H. Chiang, M.F. Wehner, A. Friedman and R. Ruedy, 2011. Sulfate aerosol control of tropical atlantic climate over the 20th century. J. Climate, 24: 2540-2555. DOI: 10.1175/2010JCLI4065.1
Chang, J.M., E.C. Su, A. Lo, H.S. Chiu and T.Y. Sung et al., 2008. PSLDoc: Protein subcellular localization prediction based on gapped-dipeptides and probabilistic latent semantic analysis. Proteins, 72: 693-710. PMID: 18260102

Chen, H., 2010. Beijing's Miyun: National leader in energy saving and pollution reduction. China Economy Newspaper.

Chimeli, A.B. and J.B. Braden, 2011. The environmental kuznets curve and optimal growth. The International Research Institute for Climate and Society, Palisades, USA.

$\mathrm{CN}, 2010$. Beijing qiangjin solar energy publishes solar water heater cost. China Net.

CNEN, 2009. How can Beijing's Miyun be the national leader of energy saving and pollution reduction? China New Energy Network.

CSEN, 2009. Solar water heater market to explode. China Solar Energy News.

Dasgupta, S., K. Hamilton, K.D. Pandey and D. Wheeler, 2006. Environment during growth: Accounting for governance and vulnerability. World Dev., 34: 1597-1611. DOI: 10.1016/j.worlddev.2005.12.008

Deng, L., Q. Shen and L. Wang, 2009. Housing Policy and Finance in China: A Literature Review. U.S. Department of Housing and Urban Development.

Economy, E., 2004. The River Runs Black: The Environmental Challenge to China's Future. 1st Edn., Cornell University Press, ISBN-10: 0801489784, pp: 337.

Esty, D.C., M.A. Levy, C.H. Kim, A. De Sherbinin and T. Srebotnjak et al., 2008. Environmental Performance Index. Yale Center for Environmental Law and Policy.

Ezzati, M., B.H. Singer and D.M. Kammen, 2001. Towards an integrated framework for development and environment policy: The dynamics of Environmental Kuznets Curves. World Devel., 29, 1421-1434. DOI: 10.1016/S0305-750X(01)00044-4

GAD, 2013. GAD-Renewable Energy Policy Network for the 21 st Century. Green Africa Directory.

Johansson, P., 1998. Stairway to sustainability. Earthwatch, 18: 28-37.

Laufer, D. and S. Martina, 2011. The implementation of solar home systems as a poverty reduction strategyA case study in Sri Lanka. Energy Sustain. Dev., 15: 330-336. DOI: 10.1016/j.esd.2011.07.002 
Liu, L., 2008. Sustainability efforts in China: Reflections on the environmental kuznets curve through a locational evaluation of "eco-communities". Annals Assoc. Am. Geograph., 98: 604-629. DOI: $10.1080 / 00045600802013452$

Liu, L., 2009. Urban environmental performance in China: A sustainability divide? Sustain. Dev., 17: 118. DOI: $10.1002 / \mathrm{sd} .356$

Liu, L., 2010a. 'Made in China: Cancer Villages. Environment: Science and Policy for Sustainable Development.

Liu, L., 2010b. Field research notes from interviews with Ninghai government officials, agriculturalists. Residents and Environmental Researchers.

Liu, L., 2011. A regional divide in sustainability performance in China: geography, governance and income. Sustainable Devel., 19: 250-262. DOI: 10.1002/sd.432

Liu, L.Q., Z.X. Wang, H.Q. Zhang and Y.C. Xue, 2010. Solar energy development in China-A review. Renewable and Sustainable Energy Rev., 14: 301311. DOI: 10.1016/j.rser.2009.08.005

Luo, Z.T. and L.S. Shi, 2004. Research Report on the Development of China's Solar Water Heating Industry. China Environmental Science Publisher. Beijing.

Ninghai, C.E.D.B., 2010. Ningbo City New Energy Industrial Base (Ninghai County) Economic Transition and Upgrading Implementation Plan (2010-2012). Ninghai Government Document.

Purohit, P. and A. Michaelowa, 2008. CDM potential of SPV lighting systems in India. Mitigat. Adapt. Strategies Global Change, 13: 23-46. DOI: 10.1007/s11027-006-9078-X

Scherr, S.J. and S. Yadav, 1996. Land degradation in the developing world: Implications for food, agriculture and the environment to 2020. International Food Policy Research Institute.

Shafik, N., 1994. Economic development and environmental quality: An econometric analysis. Oxf. Econ., 46: 757-773.

TTN, 2009a. Tianren (Nature-Society) 'Over 30.5 million Chinese household are using biogas for cooking. Tianren (Nature-Society) Trade News.

TTN, 2009b. Tianren (Nature-Society). 'Three extension" to enlarge the using of biogas. Tianren (Nature-Society) Trade News.

TTN, 2009c. Tianren (Nature-Society) 'China 1st CDM program of Household Biogas Plant is successfully registered. Tianren (Nature-Society) Trade News.
Urmee, T. and D. Harries, 2009. 'A survey of solar PV program implementers in Asia and the Pacific regions. Energy Sustain. Dev., 13: 24-32. DOI: 10.1016/j.esd.2009.01.002

VanderZanden, A., 2008. How green is their growth. Global Envision.

Wallace, W. and Z. Wang, 2006. Solar energy in China: Development trends for solar water heaters and photovoltaics in the urban environment. Bull. Sci. Technol. Soc., 26: 135-140. DOI: 10.1177/0270467606286948

Wang, X. and B. Hua, 2005. Exergy analysis of domestic-scale solar water heaters. Rene. Sust. Ene. Rev., 9: 638-645. DOI: 10.1016/j.rser.2004.04.007

Wang, Z., 2010. Prospectives for China's solar thermal power technology development. Energy, 35: 44174420. DOI: 10.1016/j.energy.2009.04.004

Watts, J., 2010a. When a Billion Chinese Jump: How China will Save Mankind--Or Destroy it. 1st Edn., Scribner, New York, ISBN-10: 1439141932, pp: 448.

Watts, J., 2010b. 'China's 'cancer villages' reveal dark side of economic boom. Guardian,

WB, 1992. World Development Report 1992: Development and the Environment. 1st Edn., Oxford University Press, USA., ISBN-10: 0195208765, pp: 320.

$\mathrm{WN}, 2009$. Low startup and high profit lead to business opportunity in SWH production. Wangyi News.

Xia, Q., 2007. Turning to a new chapter for Miyun development. Frontline.

Xiangnian, 2010. Xiangnian invented vacuum tube solar water heater technology through technological innovation.

YPAIO, 2009. Government pays 500 Yuan for each SWH installation in rural areas. Yunnan Province Agricultural Information Office.

Yuan, J., K.C.C. Cheng, R.L. Johnson, R. Huang and S. Pattaradilokrat et al., 2011. Chemical genomic profiling for antimalarial therapies, response signatures and molecular targets. Science, 333: 724729. DOI: $10.1126 /$ science. 1205216

Zhao, K., C.W. Tung, G.C. Eizenga, M.H. Wright and M.L. Ali et al., 2011. Genome-wide association mapping reveals a rich genetic architecture of complex traits in Oryza sativa. Nat. Commun., 2: 467-467. DOI: $10.1038 /$ ncomms 1467 